\title{
Optimized pH condition of protein extraction of Gastrodia elata Blume by alkaline method
}

\author{
Hye-Lim Jang, Kyung-Young Yoon* \\ Department of Food and Nutrition, Yeungnam University, Gyeongsan 719-749, Korea
}

\section{알칼리에 의한 천마 단백질 추출의 최적 $\mathrm{pH}$ 조건}

\author{
장혜림 · 윤경영* \\ 영남대학교 식품영양학과
}

\begin{abstract}
This study investigated the optimum $\mathrm{pH}$ condition for the efficient extraction of protein from Gastrodia elata Blume. Five extraction $\mathrm{pH}$ values $(8,9,10,11$, and 12$)$ and three precipitation $\mathrm{pH}$ values $(2,4$, and 6$)$ were used. The protein content, browning degree, and recovery yield of the protein obtained under each $\mathrm{pH}$ condition were determined. Most of the G. elata Blume was made up of carbohydrates, and its protein content was also high. The amount of the extracted protein increased according to the increase in the extraction $\mathrm{pH}$, but did not significantly differ between $\mathrm{pH} 8$ and $\mathrm{pH} 9$. The browning degree of the protein significantly increased as the extraction $\mathrm{pH}$ increased. The greatest amount of protein was precipitated at $\mathrm{pH} \mathrm{4,} \mathrm{the} \mathrm{recovery} \mathrm{yield} \mathrm{of} \mathrm{which} \mathrm{was} \mathrm{also} \mathrm{the} \mathrm{highest.} \mathrm{As}$ a result, it was found that the combination of extraction $\mathrm{pH} 9$ and precipitation $\mathrm{pH} 4$, which resulted in a 38.7\% recovery yield and a low browning degree, is the optimum condition for the efficient extraction of protein from G. elata Blume.
\end{abstract}

Key words : Gastrodia elata Blume, proximate composition, protein extraction, alkaline extraction

\section{서 론}

천마(Gastrodia elata Blume)는 난초과에 속하는 다년생 식물로 한국을 비롯하여 일본, 중국에서 널리 자생하고 있 다 $(1,2)$. 마와는 달리 엽록소가 없어 탄소동화작용을 하지 못하기 때문에 다른 기주 식물로부터 영양분을 받아 생장한 다(3). 예로부터 고혈압, 중풍, 두통, 신경성질환, 당뇨병 등에 효능이 있다고 알려져 한약재로 이용되고 있으며, 이 와 관련된 성분으로 gastrodin, 페놀성 배당체, 유황 함유 페놀성 화합물 등의 페놀성 화합물과 sterol류, cholesterol, vanillin 등이 보고되고 있다 $(4,5)$.

천마는 칼륨, 인, 칼슘, 마그네슘 등의 무기질을 많이 함

*Corresponding author. E-mail : yoonky2441@ynu.ac.kr Phone : 82-53-810-2878, Fax : 82-53-810-4768

Received 2 January 2015; Revised 10 February 2015; Accepted 12 February 2015.

Copyright (c) The Korean Society of Food Preservation. All rights reserved.
유하고 있으며, 필수아미노산과 아르기닌, 히스티딘이 골 고루 존재하고, 아스파르트산의 함량이 높다(4,6). 특히, 타 작물에 비해 단백질 함량이 매우 풍부하여 인체에서 여러 가지 생체조절기능을 나타낼 수 있기 때문에 상업적 응용가 치가 높은 작물이다. 또한 여러 매체를 통해 다양한 효능이 알려지면서 이를 이용한 가공식품 개발에 관심이 집중되고 있다(7). 그러나 천마는 2000년 이전까지 식품으로 사용할 수 없는 원료로 지정되어 이용이 제한되어 왔으며, 2000년 9월부터 규제가 풀림에 따라 식품원료로의 사용이 가능해 지긴 하였으나 식품가공 분야에서 사용할 수 있는 연구 자료가 여전히 미흡한 실정이다.

일반적으로 단백질은 출처에 따라 식물성 단백질과 동물 성 단백질로 분류된다. 동물성 단백질은 분해 시 생성되는 독성물질 때문에 섭취 시 아토피나 각종 알레르기 등이 발생할 수 있다. 이에 따라 소비자들은 식물성 단백질에 대한 관심이 증가하고 있으며, 다양한 식물성 식품으로부 터 양질의 단백질을 얻기 위한 연구가 다수 진행되고 있다. 그러나 단백질은 그 자체로 용해성, 기포성, 유화성과 같은 
기능성이 낮아 식품가공 적성이 떨어진다. 이를 향상시키 기 위해 여러 식품가공 분야에서는 물리·화학적 또는 효소 적 추출법을 사용하여 단백질을 추출하고 있으며, 얻어진 양질의 단백추출물은 다양한 식품에 첨가물로 이용되고 있다(8). 대표적인 단백질 추출 방법 중 하나인 알칼리 추출 법은 다른 효소적 방법이나 물리적 방법보다 수율은 낮으나 비용이 저렴하여 여러 가지 식품에서 단백질을 추출하는데 사용된다(9-12). 또한 효소적 추출 시 단백분해효소의 작용 을 용이하게 하기 위한 전처리 방법으로도 이용되고 있다. 그러나 알칼리 추출 시 사용되는 용출 및 침전 $\mathrm{pH}$ 는 시료에 따라 차이가 있으며, 추출되는 단백질의 종류와 양 뿐만 아니라 단백질의 품질 저하에 미치는 영향이 크므로 단백질 추출조건을 정확히 확립하는 것이 무엇보다 중요하다 (10-12).

따라서 본 연구에서는 알칼리 사용에 따른 갈변을 최소 화하고 영양적으로 우수한 천마 단백질을 보다 효율적으로 추출하기 위하여 용출 및 침전 $\mathrm{pH}$ 조건을 설정하고자 하였 다. 즉, 천마 단백질의 용출 및 침전 $\mathrm{pH}$ 를 달리하여 단백질 을 추출 및 침전시키고, 각 $\mathrm{pH}$ 에 따른 단백질의 갈변도와 함량을 측정하여 알칼리 추출의 최적 $\mathrm{pH}$ 조건을 설정하고 자 하였다.

\section{재료 및 방법}

\section{실험재료}

본 실험에서는 2012년 4월 전라북도 무주군에서 수확하 여 건조시킨 건천마를 믹서기(M-1211, Starion, Busan, $\mathrm{Korea}$ 로 곱게 간 다음, $60 \mathrm{mesh}$ 의 체에 통과시켜 $-40^{\circ} \mathrm{C}$ 에 보관하면서 실험에 사용하였다.

\section{일반성분 분석}

천마의 일반성분은 수분, 조지방, 조회분, 조단백, 조섬유 의 함량을 측정하여 평가하였다. 즉, 수분은 수분자동측정 기(FD-720, Kett, Tokyo, Japan)를, 조지방은 조지방자동추 출기(Soxtec 2050, Foss, Hoganas, Sweden)를 이용하여 측정 하였으며, 조회분은 직접회화법으로, 조단백질은 Micro Kjeldahl 장치(Distillation Unit B-323, Buchi, Flawil, Switzerland)를 이용하여 측정하였다. 조섬유는 조섬유자동 추출기(Fiber test F-6, Raypa, Barcelona, Spain)를 이용하여 측정하였으며, 탄수화물은 시료 전체를 $100 \%$ 로 하고 수분, 조 단백, 조지방, 조회분 함량(\%)을 감한 것으로 산출하였다.

\section{탈지 천마 제조}

지질과 결합되어 있는 단백질을 분리하기 위해 천마분말 의 지질을 $\mathrm{Ju}$ 등(13)의 방법을 약간 변형하여 제거하였다. 즉, 천마분말과 n-hexane(Duksan Co., Ansan, Korea)을 1:1
비율로 섞어 $25^{\circ} \mathrm{C}$ 에서 48 시간 동안 교반시켰으며, 교반 후 감압농축기(R-124, Buchi, Flawil, Switzerland)로 hexane을 날려 보내고 동결건조(FD-1, Eyela, Tokyo, Japan)하여 단백 질 추출에 이용하였다.

\section{탈지 천마 단백질의 알칼리 추출}

탈지 천마 단백질의 알칼리 용출은 Gnanasambandam과 Hettiarachchy(9)의 방법을 약간 변형하여 추출하였다. 용출 $\mathrm{pH}$ 에 따른 단백질 추출 정도를 비교하기 위해 각각의 탈지 천마를 다양한 알칼리 조건에서 용출시켰다. 즉, 탈지 천마 $10 \mathrm{~g}$ 에 $80 \mathrm{~mL}$ 의 증류수를 넣고 $1 \mathrm{~N} \mathrm{NaOH}$ 를 이용하여 $\mathrm{pH}$ 를 $8,9,10,11$ 및 12 로 조정하였다. 이 혼합물을 상온에서 60 분간 교반하여 $10,000 \mathrm{rpm}$ 에서 30 분 동안 원심분리 (Supra-21K, Hanil, Incheon, Korea)한 다음 상등액을 취하 였다.

\section{알칼리 추출 단백질의 등전점 침전}

다양한 알칼리 조건에서 추출된 탈지 천마 단백질은 등 전점 침전 $\mathrm{pH}$ 에 따른 단백질 추출 정도를 비교하기 위해 용출 $\mathrm{pH}$ 당 각각의 침전 $\mathrm{pH}$ 를 2, 4 및 6으로 조정하여 침전시 켰다(10). 즉, 추출된 단백질 분획을 $1 \mathrm{~N} \mathrm{HCl}$ 을 이용하여 $\mathrm{pH}$ 를 조정하였으며, 30 분 동안 상온에서 방치한 다음 $10,000 \mathrm{rpm}$ 에서 원심분리(Supra-21K, Hanil)하여 침전 단백 질을 얻었다. 얻어진 침전 단백질은 중량대비 $1: 2(\mathrm{w} / \mathrm{v})$ 의 증류수를 가하여 여러 차례 수세한 후, 다시 원심분리하여 침전물을 얻었고 다시 증류수를 가하여 충분히 균질화하였 다. 균질화한 단백질 수용액의 $\mathrm{pH}$ 를 7로 중화시켰으며, 얻은 단백질 수용액의 단백질 함량을 측정하는데 사용하였다.

\section{갈변도 측정}

알칼리 용출에 의해 얻은 탈지 천마 단백질의 갈변도는 Song 등(14)의 방법에 따라 흡광도를 측정(U-2900, Hitachi, Tokyo, Japan)하여 나타내었다. 즉, 각 시료에 단백질 응집 으로 인한 파장의 산란을 최소화하기 위해 $16 \%(\mathrm{w} / \mathrm{v})$ sodium dodecyl sulfate(SDS)를 첨가하였으며, 대조구는 증 류수에 $16 \% \mathrm{SDS}$ 를 첨가하여 측정하였다.

\section{단백질 함량 측정}

용출 단백질과 침전 단백질의 단백질 함량은 bicinchoninic $\operatorname{acid}(\mathrm{BCA})$ 법(15)으로 측정하였다. 시료 $20 \mu \mathrm{L}$ 에 $\mathrm{BCA}$ reagent(bicinchoninic acid solution : copper(П) sulfate pentahydrate $4 \%$ solution=50 : 1 , v/v) $160 \mu \mathrm{L}$ 를 혼합하여 $37^{\circ} \mathrm{C}$ 에서 30 분간 반응시켰으며, $560 \mathrm{~nm}$ 에서 흡광도를 측정 (Epoch microplate spectrophotometer, BioTek, Winooski, VT, USA)하였다. 이 때 단백질 함량은 bovine serum albumin(BSA)을 표준품으로 작성한 검량곡선을 이용하여 산출하였다. 


\section{통계분석}

본 연구의 결과는 3회 이상 반복 실험으로 얻어진 값의 평균과 표준편차로 나타내었으며, 각 실험결과에 대한 통 계분석은 SPSS 통계 프로그램(Statistics Package for the Social Science, 21.0, SPSS Inc., Chicago, IL, USA)을 사용하 여 분석하였다. 즉, 각 실험군 간의 차이를 유의수준 $\mathrm{p}<0.05$ 에서 one-way ANOVA(Analysis of Variation)로 분석한 뒤 Duncan's multiple range test로 평균치간의 유의적 차이를 검증하였다.

\section{결과 및 고찰}

\section{천마의 일반성분}

천마의 일반성분을 분석한 결과는 Table 1 과 같다. 수분 은 $15.17 \%$ 로 Chung과 $\mathrm{Ji}(4)$ 의 $11.8 \%, \mathrm{Kim}$ 등(16)의 $3.25 \%$, $\mathrm{Kim}$ 등(17)의 $7.44 \%$ 에 비해 높은 함량을 보였으며, 이는 유통되는 천마의 건조방법에 따른 차이로 판단된다. 수분 을 제외한 천마의 주성분은 탄수화물과 단백질로 각각 $73.81 \%, 5.95 \%$ 를 차지하였다. 대부분의 연구결과 천마의 주성분은 탄수화물로 조사되었으며, 타 작물에 비해 단백 질 함량이 높은 것으로 확인되었다 $(1,4,16,17)$. 조지방 함량 은 약 $2 \%$ 로 측정되었으며, 무기질이 $3.10 \%$ 로 Shin 등(1) 및 Chung과 Ji(4)의 연구 결과와 유사하였다. 조섬유는 $0.09 \%$ 로 가장 적은 함량을 나타내었으며, 약 $3 \%$ 로 측정되 었던 Kang 등(18)의 연구 결과에 비해 낮은 것으로 확인되 었다.

Table 1. Proximate composition of the Gastrodia elata Blume

\begin{tabular}{cc}
\hline Component & Contents $(\%)$ \\
\hline Moisture & $15.17 \pm 0.04$ \\
Carbohydrate & $73.81 \pm 0.06$ \\
Crude protein & $5.95 \pm 0.01$ \\
Crude fat & $1.97 \pm 0.02$ \\
Crude ash & $3.10 \pm 0.01$ \\
Crude fiber & $0.09 \pm 0.01$ \\
\hline
\end{tabular}

Mean \pm SD $(n=3)$.

알칼리 용출 $\mathrm{pH}$ 가 단백질 추출에 미치는 영향

알칼리 추출 시 $\mathrm{pH}$ 변화에 따른 단백질 함량 및 갈변도를 살펴보기 위해 용출 $\mathrm{pH}$ 에 따른 단백질 함량과 갈변도를 측정하였으며, 결과는 Fig. 1에 나타내었다. 단백질 함량은 대부분 용출 $\mathrm{pH}$ 가 증가할수록 유의적으로 증가하였으나 $\mathrm{pH}$ 9와 $\mathrm{pH} 10$ 에서는 유의적인 차이를 보이지 않았다. $\mathrm{pH}$ 가 높아짐에 따라 단백질 추출량이 점차 증가하는 것은 누에번 데기의 $\mathrm{pH}$ 에 따른 단백질 함량을 측정한 Kwon 등(8)의
연구 결과와 미강의 $\mathrm{pH}$ 에 따른 단백질 용출량을 측정한 $\mathrm{Kim}$ 등(10)의 연구 결과와 유사하였다. 단백질의 갈변도는 $\mathrm{pH}$ 가 증가함에 따라 모든 구간에서 급격한 증가를 보였으 며, $\mathrm{pH} 9$ 이후부터는 색이 확연히 진해지기 시작하였다. 높은 알칼리 조건은 당과 필수아미노산인 lysine의 glycosylamine 반응을 촉진시켜 비효소적 갈변을 증가시키 며, lysine의 구조적 변형으로 체내에서 단백질의 흡수를 감소시킨다 $(19,20) . \operatorname{Kim}$ 과 $\operatorname{Park}(21)$ 은 단백질 추출 $\mathrm{pH}$ 가 증가할수록 용해도가 증가하며 영양저해인자인 phytate를 감소시킨다고 하였으나, 단백질의 색이 어두워 적절한 추 출 $\mathrm{pH}$ 를 설정하는 것이 중요하다고 보고하였다. Wang 등 (22)은 단백질 추출에 있어 높은 알칼리 조건은 섬유질과 같은 다른 성분들도 함께 용출되어 품질을 떨어뜨리고 lysinoalanine과 같은 잠재독소물질이 생성될 수 있다고 보 고하였다. 따라서 탈지 천마 단백질의 용출 $\mathrm{pH}$ 는 단백질 함량과 갈변정도를 고려하여 $\mathrm{pH}$ 9가 적절한 것으로 판단 된다.

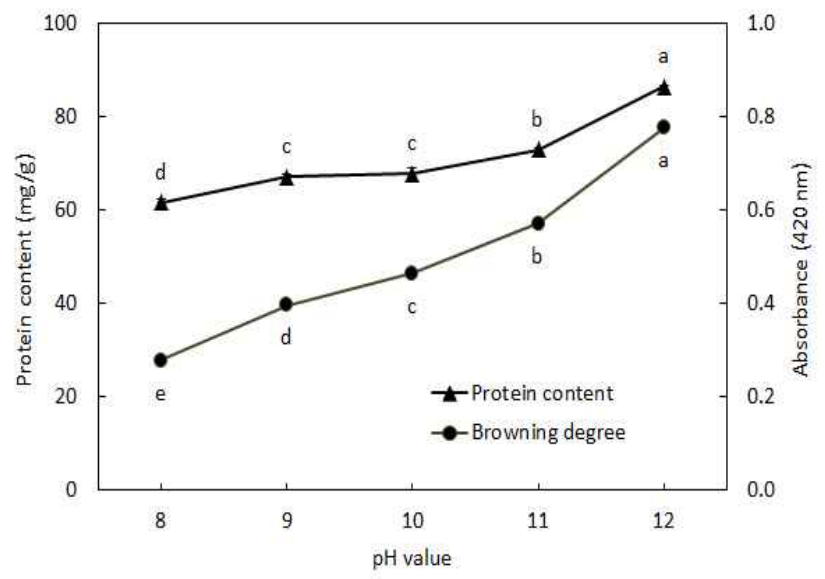

Fig. 1. Protein content and browning degree of the extracts obtained at different extraction $\mathrm{pH}$ values.

The values represent the mean $\pm \mathrm{SD}(\mathrm{n}=3)$. The means followed by the same letter did not significantly $(\mathrm{p}<0.05)$ differ in Duncan's multiple range test.

\section{침전 $\mathrm{pH}$ 가 단백질 함량에 미치는 영향}

다양한 알칼리 조건에서 추출된 시료를 각각 $\mathrm{pH} 2,4$ 및 6에서 침전시킨 후 회수한 상등액과 침전 단백질의 단백 질 함량을 비교한 결과는 Fig. 2와 같다. $\mathrm{pH} 12$ 에서 용출된 단백질을 제외한 모든 시료에서 $\mathrm{pH}$ 4로 침전시킨 pellet의 단백질 함량이 유의적으로 많았으며, $\mathrm{pH} 12$ 에서 용출시켜 $\mathrm{pH}$ 4로 침전시킨 pellet의 경우 유의적인 차이는 보이지 않았으나 가장 많은 단백질을 함유하고 있었다. 또한 상등 액의 단백질 함량은 $\mathrm{pH} 8$ 에서 용출된 시료를 제외하고 모든 실험군에서 $\mathrm{pH}$ 4로 침전시킨 것이 가장 적은 것으로 확인되 었다. 용출 $\mathrm{pH}$ 가 증가할수록 상등액에 남아있는 단백질의 비율이 약 $45 \%$ 에서 $15 \%$ 로 $30 \%$ 감소하는 경향을 보였으며, $\mathrm{pH} 4$ 에서 침전된 단백질은 전체 단백질의 약 $10 \%$ 만이 상등 
액에 포함되어 있었다. 반면 $\mathrm{pH} 2$ 또는 6에서 침전 시 $20 \%$ 정도의 단백질이 상등액에 남아있는 것으로 확인되었 다. Kim 등(10)은 미강단백질의 침전 $\mathrm{pH}$ 조사 결과, $\mathrm{pH}$ 4 의 상등액에 남아있는 단백질의 양이 다른 $\mathrm{pH}$ 에 비해 가장 적었다고 보고하여 본 연구 결과와 유사하였다. 반면, 회수 한 단백질의 약 $15 ~ 30 \%$ 가 상등액에 여전히 남아있는 것으 로 보고하여 본 연구 결과와 차이를 보였다. 즉, 미강 단백질 에 비해 천마 단백질은 $\mathrm{pH}$ 4에서 단백질 추출 효율이 크게 증가했음을 확인할 수 있었다.

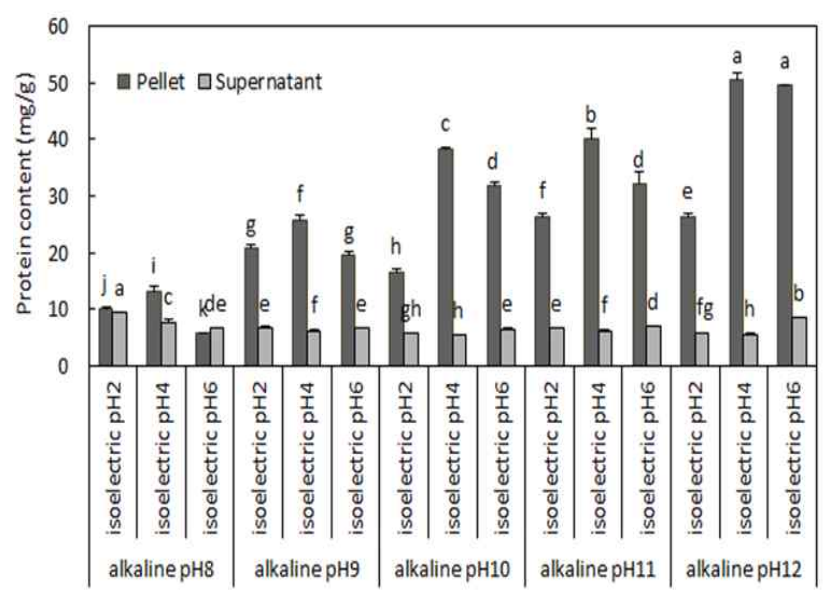

Fig. 2. Comparison of the protein contents of the pellet and the supernatant obtained at different extraction $\mathrm{pH}$ and precipitation $\mathrm{pH}$ values.

The values represent the mean $\pm \mathrm{SD}(\mathrm{n}=3)$. The means followed by the same letter did not significantly $(\mathrm{p}<0.05)$ differ in Duncan's multiple range test.

\section{용출 및 침전 $\mathrm{pH}$ 에 따른 단백질 회수율}

탈지 천마 단백질의 용출 및 침전 $\mathrm{pH}$ 에 따른 단백질 회수 율을 나타낸 결과는 Fig. 3과 같다. 모든 용출 $\mathrm{pH}$ 에서 침전 $\mathrm{pH}$ 가 4일 때 가장 많은 단백질을 회수할 수 있었으며, 침전 $\mathrm{pH}$ 가 2인 경우에는 대부분 가장 낮은 회수율을 나타내었으 나 용출 $\mathrm{pH}$ 가 8 과 9 인 조건에서는 침전 $\mathrm{pH}$ 가 6인 경우보다 더 높은 회수율을 보였다. 단백질을 구성하는 아미노산은 전기적 성질에 따라 등전점이 달리 나타나며, 이에 따라 산성, 중성, 염기성으로 나눌 수 있다. 대부분 중성이나 glutamic acid는 등전점의 $\mathrm{pH}$ 가 약 4 로 대표적인 산성아미 노산이다. 천마 단백질의 주요 아미노산인 glutamic acid의 등전점이 $\mathrm{pH}$ 4이므로 용해도는 $\mathrm{pH}$ 가 4일 때 가장 낮고 단백질의 침전이 가장 많이 일어난다(22). 따라서 탈지 천마 단백질의 회수율은 용출 $\mathrm{pH}$ 에 상관없이 $\mathrm{pH}$ 가 4 일 때 가장 높은 것으로 확인되었다. 비록 용출 $\mathrm{pH} 12$, 침전 $\mathrm{pH} 4$ 에서 단백질 회수율이 $58.5 \%$ 로 가장 높았으나 심한 갈변으로 인해 단백질의 추출 조건으로는 바람직하지 않은 것으로 나타났다. 또한 용출 $\mathrm{pH} 10$ 과 11 , 침전 $\mathrm{pH} 4$ 의 경우도 각각 $56.9 \%, 55.1 \%$ 의 높은 회수율을 보이고 있으나 갈변이 심하여 단백질의 품질이 떨어질 것으로 판단된다. 따라서
$38.7 \%$ 의 회수율을 보인 용출 $\mathrm{pH}$ 9와 침전 $\mathrm{pH}$ 4가 천마 단백질 추출을 위한 최적 추출 $\mathrm{pH}$ 로 판단된다.

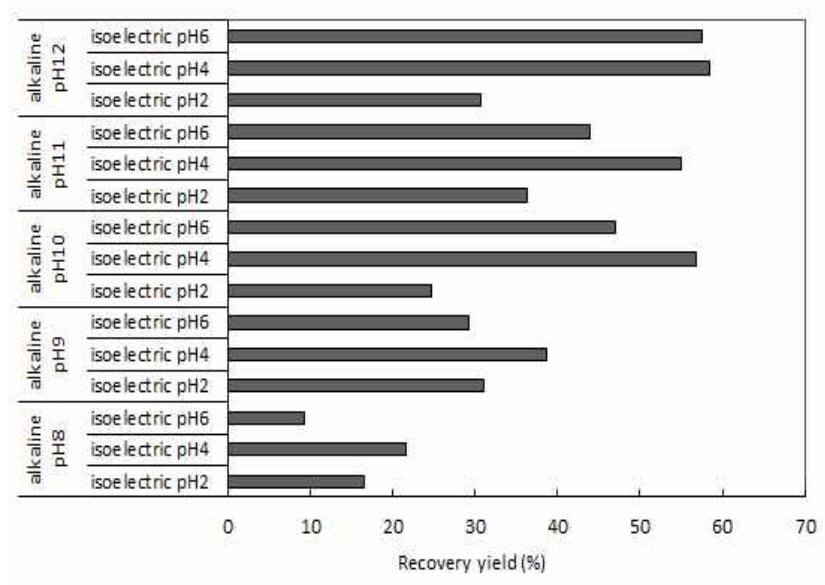

Fig. 3. Recovery yield of the protein according to the extraction $\mathrm{pH}$ and the precipitation $\mathrm{pH}$.

\section{요 약}

본 연구에서는 알칼리 사용에 따른 갈변을 최소화하고 영양적으로 우수한 천마 단백질을 보다 효율적으로 추출하 기 위하여 용출 및 침전 $\mathrm{pH}$ 에 따른 단백질의 갈변도와 함량 을 측정함으로써 탈지 천마 단백질 알칼리 추출의 최적 $\mathrm{pH}$ 조건을 설정하고자 하였다. 천마의 수분은 약 $15 \%$ 로 측정되었으며, 대부분 탄수화물로 구성되어 있었고, 단백 질의 함량이 높은 것으로 확인되었다. 이러한 단백질을 다 양한 $\mathrm{pH}$ 에서 용출시킨 결과 $\mathrm{pH}$ 가 증가함에 따라 용출된 단백질의 양이 증가하였으며, 갈변도 또한 증가함을 보였 다. 침전 $\mathrm{pH}$ 에 따른 단백질 함량은 $\mathrm{pH}$ 4에서 침전된 pellet이 가장 많은 함량을 나타내었으며, 상등액의 단백질 함량 또 한 대부분 $\mathrm{pH}$ 4로 침전시킨 경우 가장 적은 것으로 확인되 었다. 뿐만 아니라 단백질의 회수율도 침전 $\mathrm{pH}$ 가 4일 때 가장 높은 값을 나타내었다. 따라서 갈변도와 단백질 함량 을 고려한 탈지 천마 단백질 추출을 위한 최적조건은 용출 $\mathrm{pH}$ 9와 침전 $\mathrm{pH}$ 4로 결정되었다.

\section{References}

1. Shin CS, Park CK, Lee JW, Lee JG, Jang CK, Kim YK (1999) Analysis of the components with freeze drying and steam drying of Gastrodia elata Blume. J Korean Soc Food Sci Nutr, 28, 1058-1063

2. Choi SR, Jang I, Kim CS, You DH, Kim JY, Kim YG, Ahn YS, Kim JM, Kim YS, Seo KW (2011) Changes 
of components and quality in Gastrodiae rhizoma by different dry methods. Korean J Medicinal Crop Sci, 19, 354-361

3. Ha JH, Lee DU, Yong CS, Kim JA, Huh K (1999) Agonistic activities to the benzodiazepine receptor by extracts of medicinal plants (II). Activities of component and active fractions from Gastrodia elata. Kor J Pharmacogn, 30, 284-289

4. Chung HS, Ji GE (1996) Composition and functionality of Chonma. Korean J Food Sci Technol, 28, 53-57

5. Lin JH, Liu YC, Hau JP, Wen KC (1996) Parishins B and $\mathrm{C}$ from rhizomes of Gastrodia elata. Phytochem, 42, 549-551

6. Kim JK, Cha WS, Park JH, Oh SL, Cheon SH, Chung SK (1997) Studies on the mineral component and antioxidative activity of Gastrodia elata Blume. Korean J Post-Harvest Sci Technol Agri Products, 4, 317-321

7. Lee BY, Choi HS, Hwang JB (2002) Analysis of food components of Gastrodiae Rhizoma and changes in several characteristics at the various drying conditions. Korean J Food Sci Technol, 34, 37-42

8. Kwon HJ, Lee KH, Kim JH, Chun SS, Cho YJ, Cha WS (2006) Effect of protease on the extraction and properties of the protein from silkworm pupa. J Korean Soc Appl Biol Chem, 49, 304-308

9. Gnanasambandam R, Heitiarachchy NS (1995) Protein concentrates from unstabilized and stabilized rice bran : preparation and properties. J Food Sci, 60, 1066-1069

10. Kim W, Jung SY, Hong KW (2011) Optimum pH condition of defatted rice protein extraction by alkaline method. Food Eng Prog, 15, 143-147

11. Shen L, Wang X, Wang Z, Wu Y, Chen J (2008) Studies on tea protein extraction using alkaline and enzyme methods. Food Chem, 107, 929-938

12. Batista I (1999) Recovery of proteins from fish waste products by alkaline extraction. Eur Food Res Technol, 210, 84-89
13. Ju ZY, Hettiarachchy NS, Rath N (2001) Extraction, denaturation and hydrophobic properties of rice flour proteins. J Food Sci, 66, 229-232

14. Song PS, Chichester CO, Stadtman FH (1966) Kinetic behavior and mechanism of inhibition in the Maillard reaction. I. Kinetic behavior of the reaction between D-glucose and glycine. J Food Sci, 31, 906-913

15. Smith PK, Krohn RI, Hermanson GT, Mallia AK, Gartner FH, Provenzano MD, Fujimoto EK, Goeke NM, Olson BJ, Klenk DC (1985) Measurement of protein using bicinchoninic acid. Anal Biochem, 150, 76-85

16. Kim SH, Kim IH, Kang BH, Lee SH, Kim JH, Lee JM (2006) Hot-water extraction condition of Gastrodia elata Blume by response surface methodology. Korean J Food Preserv, 13, 131-137

17. Kim JM, Moon YS, Yoon KY, Suh SG (2010) Quality properties and preference of fermented Gastrodia elata Blume. Korean J Hort Sci Technol, 28, 507-514

18. Kang TS, Kong YJ, Kwon HJ, Choi BK, Hong JG, Park YK (2002) A studies on the chemical composition and in vitro biological activities of a hot water extracts of Gastrodia elata. Korean J Mycol, 30, 136-141

19. Ajandouz EH, Puigserver A (1999) Nonenzymatic browning reaction of essential amino acids : effect of $\mathrm{pH}$ on caramelization and Maillard reaction kinetics. J Agric Food Chem, 47, 1786-1793

20. Ajandouz EH, Tchiakpe LS, Dalle Ore F, Benajiba A, Puigserver A (2001) Effects of $\mathrm{pH}$ on caramelization and Maillard reaction kinetics in fructose-lysine model systems. J Food Sci, 66, 926-931

21. Kim EJ, Park JR (1995) The effect of protein extraction $\mathrm{pH}$ on the components of sesame protein concentrates. J Korean Soc Food Nutr, 24, 613-618

22. Wang M, Hettiarachchy NS, Qi M, Burks W, Siebenmorgen $T$ (1999) Preparation and functional properties of rice bran protein isolate. J Agric Food Chem, 47, 411-416 